Supplementary Information

\title{
Chelating Diamide Based Rate Enhancement of Intramolecular Alkene Hydroaminations Catalyzed by a Neutral Sc(III) Complex
}

\author{
Joon Young Kim and Tom Livinghouse* \\ Department of Chemistry, Montana State University \\ Bozeman, MT 59717 \\ livinghouse@chemistry.montana.edu
}

\begin{abstract}
Table of Contents
Experimental procedure and data of compounds: S2-S11

References: S12

Selected spectra: S13-S23
\end{abstract}

cf.) this is the 0th version of using "track changes" function. 


\section{General information}

Melting points were obtained using a Mel-Temp II apparatus equipped with a digital thermometer and are uncorrected. High Resolution Mass spectra were obtained on a Bruker MicroTOF spectrometer.

${ }^{1} \mathrm{H}$ NMR spectra were recorded on a Bruker AVANCE DPX-300 (300MHz), or AVANCE DPX-500 (500MHz) spectrometer. Chemical shifts are reported in ppm from tetramethylsilane with the residual protic solvent resonance as the internal standard (chloroform: $\delta 7.24 \mathrm{ppm}$, or benzene: $\delta 7.16 \mathrm{ppm}$ ). Data are reported as follows: chemical shift, multiplicity $(\mathrm{s}=$ singlet, $\mathrm{d}=$ doublet, $\mathrm{t}=$ triplet, $\mathrm{q}=$ quartet, $\mathrm{m}=$ multiplets, br s = broad singlet, br d = broad doublet, br m = broad multiplet), integration, coupling constants (in $\mathrm{Hz}$ ), and assignments. ${ }^{13} \mathrm{C}$ NMR spectra were recorded on a Bruker AVANCE DPX-300 (300MHz), or AVANCE DPX-500 (500MHz) spectrometer with complete decoupling. Chemical shifts are reported in ppm from tetramethylsilane with the solvent as the internal standard $\left(\mathrm{CDCl}_{3}: \delta 77.0 \mathrm{ppm}\right)$.

Analytical thin layer chromatography was performed on Polygram ${ }^{\circledR}$ SIL G/UV 254 $1.25 \mathrm{~mm}$ silica gel plates with a fluorescent indicator. Flash chromatography was performed on Merck silica gel 60. Solvents for extraction and flash chromatography were reagent grade.

All experiments were carried out under an argon atmosphere using standard anaerobic methods. Organoscandium complexes were manipulated under an argon atmosphere in a glove box. Benzene- $\mathrm{D}_{6}$ and aminoalkenes were distilled from $\mathrm{Na}$ and $\mathrm{CaH}_{2}$ respectively, under an argon atmosphere, and stored at $-30{ }^{\circ} \mathrm{C}$ in a glove box. Aminoalkenes ${ }^{1}$, 1-amino-2,2-dimethyl-4-pentene (2a), 2-amino-5-hexene (2b), 1-amino2-methyl-4-pentene (2c), 1-amino-2-phenyl-4-pentene (2d), 5-amino-1,8-nonadiene (2f), and proligands ${ }^{2}, N, N^{\prime}$-bis(2-isopropylphenyl)ethane-1,2-diamine (6), $N, N^{\prime}$-bis( $P, P$-diisopropylthiophosphinyl)-2,2-dimethyl-1,3-propanediamine (4) were prepared according to reported procedures. 


\section{General Procedure for Intramolecular Alkene Hydroaminations}

In an argon-filled glove box, $\mathrm{Sc}\left[\mathrm{N}(\mathrm{TMS})_{2}\right]_{3}$ (1a) (10.5 mg, $\left.0.02 \mathrm{mmol}\right)$, bis(isopropylphenylamino)ethylene diamine proligand 6 (5.9 mg, $0.02 \mathrm{mmol}), \mathrm{C}_{6} \mathrm{D}_{6}(0.7$ $\mathrm{mL}$ ) were introduced sequentially into a J. Young NMR tube equipped with Teflon screw

cap. The homogeneous reaction mixture was maintained at $120{ }^{\circ} \mathrm{C}$ in a constant temperature oil bath until ligand attachment was judged complete by the disappearance of the $\mathrm{Sc}\left[\mathrm{N}(\mathrm{TMS})_{2}\right]_{3}$ resonance in the ${ }^{1} \mathrm{H}$ NMR spectrum with concomitant production of $(\mathrm{TMS})_{2} \mathrm{NH}$. To the resulting complex was added the appropriate aminoalkene $2(0.4$ mmol) and the reaction mixture was subsequently heated at $60{ }^{\circ} \mathrm{C}$ or $120{ }^{\circ} \mathrm{C}$ in an oil bath to achieve hydroamination. ${ }^{1} \mathrm{H}$ NMR spectroscopy using a pulse delay of $10 \mathrm{sec}$ was employed to monitor the progress of the reaction.

\section{Preparative Scale Hydroaminations}

\section{2,5-Dimethylpyrrolidine'HCl salt}

In an argon-filled glove box, Sc[N(TMS) $]_{3}$ (1a) (44.5 mg, $0.15 \mathrm{mmol}$ ) and $N, N^{\prime}-$ bis(2-isopropylphenyl)ethane-1,2-diamine (5) (78.9 mg, $0.15 \mathrm{mmol}$ ) were introduced into a $30 \mathrm{~mL}$ sealed tube equipped with a magnetic stirring bar and degassed benzene (6.6 $\mathrm{mL}$ ) was subsequently added. The flask was sealed and the homogeneous reaction mixture was heated at $120{ }^{\circ} \mathrm{C}$ with stirring for $2 \mathrm{~h}$ to effect ligand attachment. The reaction mixture was cooled to room temperature and 2-amino-5-hexene (2a) (0.3 g, 0.38 $\mathrm{mL}, 3 \mathrm{mmol}$ ) was added via micro syringe, in the glove box. The reaction mixture was then heated to $60{ }^{\circ} \mathrm{C}$ in an oil bath with stirring for $3 \mathrm{~h}$ to complete hydroamination. The product amine and solvent were subsequently separated from the catalyst by vacuum transfer and the resultant mixture was cautiously added at $-15^{\circ} \mathrm{C}$ to a $6 \mathrm{M}$ solution of $\mathrm{HCl}$ in diethyl ether $(15 \mathrm{~mL})$. Removal of the solvents in vacuo provided the title compound (0.4 g, 98\%) as a white solid.

The ${ }^{1} \mathrm{H}$ and ${ }^{13} \mathrm{C}$ NMR spectra are identical to the reported data. ${ }^{3}$ 
${ }^{1} \mathrm{H}$ NMR (CDCl, $500 \mathrm{MHz}$ ): (trans only) $\delta$ ppm 9.54 (br s, $2 \mathrm{H},=\mathrm{NH}_{2}{ }^{+} \mathrm{Cl}^{-}$), $3.79(\mathrm{~m}, 2 \mathrm{H}$, $\mathrm{CH}), 2.18$ (m, 1H, CHH), 1.66 (m, 2H, CHH), 1.49 (d, 6H, - $\mathrm{CH}_{3}, J=7.0 \mathrm{~Hz}$ ).

${ }^{13} \mathrm{C} \mathrm{NMR}\left(\mathrm{CDCl}_{3}, 500 \mathrm{MHz}\right):($ trans $) \delta \mathrm{ppm}$ 54.8, 32.3, 18.2.

\section{Syntheses of Aminoalkenes and Its Derivatives}

\section{1-Amino-2,2-dimethyl-4-pentene (2a)}

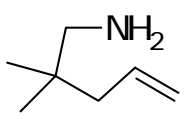

To a stirred suspension of $\mathrm{LiAlH}_{4}(2.66 \mathrm{~g}, 70 \mathrm{mmol})$ in dry $\mathrm{Et}_{2} \mathrm{O}(60 \mathrm{~mL})$ was added 2,2-dimethylpent-4-ene-1-nitrile $(3.8 \mathrm{~g}, 35 \mathrm{mmol})^{1}$ dropwise at ambient temperature. After heating at reflux overnight, the reaction mixture was cooled to $0{ }^{\circ} \mathrm{C}$ and carefully quenched via sequential addition of $\mathrm{H}_{2} \mathrm{O}(2 \mathrm{~mL}), 15 \%$ aqueous $\mathrm{NaOH}$ (2 $\mathrm{mL})$ and $\mathrm{H}_{2} \mathrm{O}(4 \mathrm{~mL})$. The mixture was subsequently stirred at room temperature for $2 \mathrm{~h}$ and anhydrous $\mathrm{MgSO}_{4}$ (4 g) was added. The suspension was filtered and extracted 3 times with diethyl ether $(15 \mathrm{~mL})$. The filtrate was concentrated in vacuo and the residue was distilled to afford $3.5 \mathrm{~g}(89 \%)$ of the title compound $2 \mathrm{a}\left(\mathrm{bp}=51-52^{\circ} \mathrm{C}\right.$ ).

${ }^{1} \mathrm{H}$ NMR $\left(\mathrm{CDCl}_{3}, 500 \mathrm{MHz}\right): \delta \mathrm{ppm}$ 5.73-5.79 (m, 1H, $\left.\mathrm{CH}=\mathrm{CH}_{2}\right), 4.98-5.08(\mathrm{~m}, 2 \mathrm{H}$, $\mathrm{CH}=\mathrm{CH}_{2}$ ), 2.45 (s, 2H, $\mathrm{NCH}_{2}$ ), 1.99 (d, 2H, $\mathrm{CH}_{2} \mathrm{CH}=, J_{\mathrm{HH}}=7.6 \mathrm{~Hz}$ ), 1.16 (br s, $2 \mathrm{H}$, $\mathrm{NH}_{2}$ ), 0.88 (s, 6H, $\mathrm{Me}_{2}$ ).

${ }^{13} \mathrm{C} \mathrm{NMR}\left(\mathrm{CDCl}_{3}, 500 \mathrm{MHz}\right): \delta \mathrm{ppm} 135.9,117.1,53.1,44.6,36.1,23.9$.

\section{2-Amino-5-hexene (2b)}

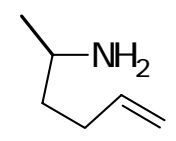

To a suspension of $\mathrm{LiAlH}_{4}(2.07 \mathrm{~g}, 47 \mathrm{mmol})$ in $60 \mathrm{~mL}$ of dry $\mathrm{Et}_{2} \mathrm{O}$ at $0{ }^{\circ} \mathrm{C}$ was added dropwise hex-5-en-2-one oxime ${ }^{2 \mathrm{a}}$ (3 g, $26.5 \mathrm{mmol}$ ). After refluxing for $3 \mathrm{~h}$, the 
reaction mixture was cooled to $0{ }^{\circ} \mathrm{C}$ and carefully quenched via sequential addition of $\mathrm{H}_{2} \mathrm{O}(2 \mathrm{~mL}), 15 \%$ aqueous $\mathrm{NaOH}(2 \mathrm{~mL})$ and $\mathrm{H}_{2} \mathrm{O}(4 \mathrm{~mL})$. The mixture was stirred at room temperature for $2 \mathrm{~h}$, and anhydrous $\mathrm{MgSO}_{4}(5 \mathrm{~g})$ was added. The suspension was filtered. The filtered cake was washed with $\mathrm{Et}_{2} \mathrm{O}$ and concentrated by distillation using a Vigreux column. The residue was purified by distillation at $92-93{ }^{\circ} \mathrm{C}$ to afford $1.66 \mathrm{~g}$ (63\%) of title compound $\mathbf{2 b}$.

${ }^{1} \mathrm{H}$ NMR (CDCl $\left.3,300 \mathrm{MHz}\right): \delta$ ppm 5.79 (m, 1H, -CH=), 4.98 (br d, 1H, =CHH, J=17.1 $\mathrm{Hz}$ ), 4.92 (br d, 1H, =CHH, J=10.2 Hz), 2.87 (m, 1H, CH), 2.07 (m, 2H, CH ) 1.38 (m, 2H, $\mathrm{CH}_{2}$ ), 1.16 (br s, 2H, NH), 1.03 (d, 3H, $\mathrm{CH}_{3}, J=6.3 \mathrm{~Hz}$ ).

${ }^{13} \mathrm{C} \mathrm{NMR}\left(\mathrm{CDCl}_{3}, 300 \mathrm{MHz}\right): \delta$ ppm 138.6, 114.4, 46.4, 39.2, 30.7, 23.9.

\section{1-Amino-2-methyl-4-pentene (2c)}

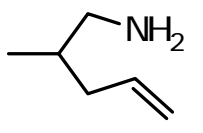

This compound was prepared as described for 2a utilizing 2-methylpent-4-ene-1nitrile ${ }^{1}(2.67 \mathrm{~g}, 28 \mathrm{mmol})$ and $\mathrm{LiAlH}_{4}(2.1 \mathrm{~g}, 56 \mathrm{mmol})$ to give $1.5 \mathrm{~g}(54 \%)$ of $2 \mathrm{c}$. The product was purified by distillation at $100-101^{\circ} \mathrm{C}$.

${ }^{1} \mathrm{H}$ NMR $\left(\mathrm{CDCl}_{3}, 300 \mathrm{MHz}\right): \delta \mathrm{ppm} 5.76(\mathrm{~m}, 1 \mathrm{H},-\mathrm{CH}=)$, 5.00 (m, 2H, =CH $), 2.61$ (dd, 1H, NCHH, J=12.6, $6.0 \mathrm{~Hz}$ ), 2.46 (dd, 1H, NCHH, J=12.6, $6.9 \mathrm{~Hz}$ ), 2.11 (m, 1H, CHH), 1.87 (m, 1H, CHH), 1.53 (m, 1H, CH), 1.27 (br s, 2H, NH$H_{2}$ ), 0.88 (d, 3H, $\mathrm{CH}_{3}, J=6.6 \mathrm{~Hz}$ ). ${ }^{13} \mathrm{C}$ NMR (CDCl, $\left.500 \mathrm{MHz}\right): \delta$ ppm 137.1, 115.8, 47.9, 38.9, 36.2, 17.3.

\section{1-Amino-2-phenyl-4-pentene (2d)}

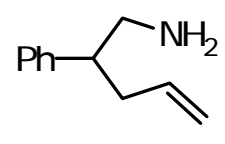

This compound was prepared according to the procedure as described for $2 \mathbf{a}$, utilizing 2-phenylpent-4-ene-1-nitrile ${ }^{1}$ (3 g, $19 \mathrm{mmol}$ ) and $\mathrm{LiAlH}_{4}(1.4 \mathrm{~g}, 38 \mathrm{mmol})$ to give $1.85 \mathrm{~g}(60 \%)$ of $\mathbf{2 d}$. The product was purified by distillation (bp $=203-204^{\circ} \mathrm{C}$ ). 
${ }^{1} \mathrm{H}$ NMR (CDCl $\left.3,300 \mathrm{MHz}\right): \delta$ ppm 7.25 (m, 5H, ArH), 5.67 (m, 1H, -CH=), 4.97 (br d, 1H, =CHH, J=17.1 Hz), 4.92 (bd, 1H, =CHH, J=10.2 Hz), 2.95 (dd, 1H, NCHH, J=12.6, $5.7 \mathrm{~Hz}$ ), 2.83 (dd, 1H, NCHH, J=12.6, 8.7 Hz), 2.67 (quintet, 1H, -CH-), 2.36 (m, 2H, $\mathrm{CH}_{2}$ ), 1.32 (br s, 2H, $\mathrm{NH}_{2}$ ).

${ }^{13} \mathrm{C} \mathrm{NMR}\left(\mathrm{CDCl}_{3}, 500 \mathrm{MHz}\right): \delta$ ppm 143.0, 136.6, 128.5, 127.9, 126.4, 116.0, 49.4, 47.4, 38.3.

\section{Preparation of 6-Amino-10-methyl-1,9-undecadiene (2e)}

6-Amino-10-methyl-1,9-undecadiene (2e) was prepared via 5 steps as described below (Scheme 1) utiilizing 6-methyl-2-heptenone.

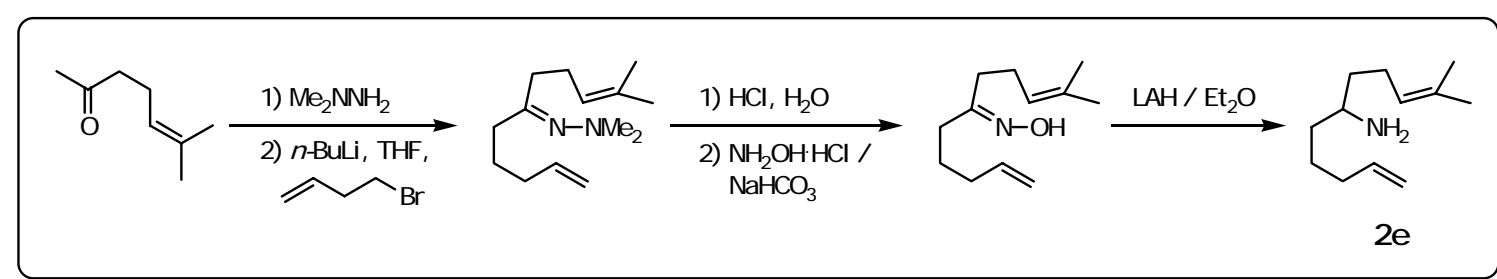

$<$ Scheme 1>

$N, N^{\prime}$-dimethyl-1-(10-methylundeca-1,9-dien-6-ylidene)hydrazine

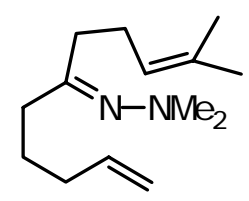

To 6-Methyl-5-heptene-2-one (3.8 g, $4.4 \mathrm{~mL}, 30 \mathrm{mmol}$ ) was added $N$,N'-dimethyl hydrazine $(2.1 \mathrm{~g}, 2.7 \mathrm{~mL}, 35 \mathrm{mmol})$ at $0{ }^{\circ} \mathrm{C}$ and stirred for $3 \mathrm{~h}$ at room temperature. The mixture was concentrated and diluted with petroleum ether. The solution was dried over $\mathrm{MgSO}_{4}$ and then filtered. The filtrate was concentrated to yield an oil which was shown to be pure by GC (a single peak, $R_{t}=6.43 \mathrm{~min}$, quantitative yield). The resulting hydrazone (3.56 g, $21.2 \mathrm{mmol})$ was dissolved in THF (100 mL) and $n$-BuLi (2.74 M solution, $8.5 \mathrm{~mL}, 23.3 \mathrm{mmol}$ ) was added at $-15{ }^{\circ} \mathrm{C}$. The mixture was stirred for $30 \mathrm{~min}$ at 
-15 ${ }^{\circ} \mathrm{C}$ and 4-bromo-1-butene $(2.35 \mathrm{~mL}, 23.3 \mathrm{mmol})$ was added dropwise at $-15^{\circ} \mathrm{C}$. The reaction mixture was allowed to warm to room temperature and stirred overnight. $\mathrm{H}_{2} \mathrm{O}$ $(20 \mathrm{~mL})$ was added to the mixture and aqueous layer was extracted with $\mathrm{Et}_{2} \mathrm{O}(2 \times 50$ $\mathrm{mL})$. The combined organic layers were washed with $\mathrm{H}_{2} \mathrm{O}(30 \mathrm{~mL})$ and dried over $\mathrm{MgSO}_{4}$. The suspension was filtered and the filtrate was concentrated. The product was purified by vacuum distillation (bp $=57{ }^{\circ} \mathrm{C}$ at $0.05 \mathrm{mmHg}$ ) to give $4.62 \mathrm{~g}$ (98\%) of pale yellow oil.

${ }^{1} \mathrm{H}$ NMR (CDCl, $500 \mathrm{MHz}$ ): $\delta$ ppm 5.73 (m, $1 \mathrm{H}, \mathrm{CH}_{2}=\mathrm{CH}$ ), 5.03 (br m, $1 \mathrm{H}, \mathrm{Me}_{2} \mathrm{C}=\mathrm{CH}$ ), $\left.4.91\left(\mathrm{~m}, 2 \mathrm{H}, \mathrm{CH}_{2}=\right), 2.36\left(\mathrm{~m}, 2 \mathrm{H},=\mathrm{CH}-\mathrm{CH}_{2}\right), 2.31(\mathrm{~s}, 6 \mathrm{H},-\mathrm{NMe})_{2}\right), 2.16(\mathrm{~m}, 4 \mathrm{H},=\mathrm{C}-$ $\left.\left(\mathrm{CH}_{2}\right)_{2}\right), 2.02\left(\mathrm{~m}, 2 \mathrm{H},-\mathrm{CH}_{2}-\mathrm{CH}=\right), 1.59\left(\mathrm{~d}, 3 \mathrm{H},=\mathrm{CMe}_{2}, \mathrm{~J}=7 \mathrm{~Hz}\right.$ ), 1.51 (d and m, mixed peak of $=\mathrm{CMe}_{2}$ and $-\mathrm{CH} 2-, \mathrm{J}=8 \mathrm{~Hz}$ ).

$\left.{ }^{13} \mathrm{C} \mathrm{NMR} \mathrm{(CDCl} 3,500 \mathrm{MHz}\right): \delta$ ppm 171.8, 138.0, 131.8, 123.4, 114.8, 47.4, 35.6, 33.4, 29.4, 26.4, 25.7, 25.0, 17.6.

\section{0-methyl-1,9-undecadiene-6-one oxime}

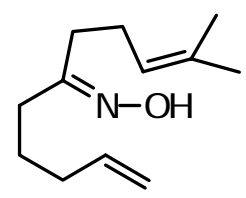

To a solution of $N, N^{\prime}$-dimethyl-1-(10-methylundeca-1,9-dien-6-ylidene)hydrazine (4.2 g, $18.8 \mathrm{mmol}$ ) and $\mathrm{CH}_{2} \mathrm{Cl}_{2}(50 \mathrm{~mL})$ was added $10 \%$ aqueous $\mathrm{HCl}(60 \mathrm{~mL}$ ) slowly at $0{ }^{\circ} \mathrm{C}$ and stirred overnight at room temperature. The mixture was separated and the aqueous layer was extracted with $\mathrm{CH}_{2} \mathrm{Cl}_{2}(2 \times 80 \mathrm{~mL})$. The combined organic layers were washed with $\mathrm{NaHCO}_{3}$ saturated solution and dried over $\mathrm{MgSO}_{4}$. The suspension was filtered and the filtrate was concentrated. The residue was subjected to column chromatography on silica gel (10\% ethyl aceteate in $n$-hexane) to give $3.2 \mathrm{~g}$ (94.4\%) of 10-methyl-1,9-undecadiene-6-one as a colorless oil. The 10-methyl-1,9-undecadiene-6one ( $3.5 \mathrm{~g}, 19.4 \mathrm{mmol})$ was dissolved in $42 \mathrm{~mL}$ of solvent ( $\mathrm{EtOH}:$ THF : $\mathrm{H}_{2} \mathrm{O}=4: 2: 1$ ) and hydroxylamine hydrochloride $(2.7 \mathrm{~g}, 38.8 \mathrm{mmol})$ was added. To this reaction mixture was added $\mathrm{NaHCO}_{3}\left(3.3 \mathrm{~g}, 38.8 \mathrm{mmol}\right.$ ) slowly at $0{ }^{\circ} \mathrm{C}$ (exothermic) and stirred 
overnight at room temperature. The suspension was filtered, the filter cake was extracted with EtOAc and the filtrate was diluted with EtOAc $(80 \mathrm{~mL})$. The solution was washed with $\mathrm{H}_{2} \mathrm{O}(10 \mathrm{~mL})$ and $\mathrm{NaCl}$ saturated solution. The organic layer was dried over $\mathrm{MgSO}_{4}$ and the suspension was filtered. The filtrate was concentrated to give pure $3.44 \mathrm{~g}$ (91\%) of the oxime as colorless oil.

${ }^{1} \mathrm{H}$ NMR $\left(\mathrm{CDCl}_{3}, 500 \mathrm{MHz}\right): \delta$ ppm 8.92 (br s, $\left.1 \mathrm{H},=\mathrm{N}-\mathrm{OH}\right), 5.78\left(\mathrm{~m}, 1 \mathrm{H}, \mathrm{CH}_{2}=\mathrm{CH}\right)$, $5.11\left(\mathrm{~m}, 1 \mathrm{H}, \mathrm{Me}_{2} \mathrm{C}=\mathrm{CH}\right.$ ), 4.99 (m, 2H, $\mathrm{CH}_{2}=$ ), 2.33 (br m, 2H, =CH-CH $), 2.19$ (m, 4H, $=\mathrm{C}-\left(\mathrm{CH}_{2}\right)_{2}$ ), 2.06 (app. sextet, 2H, $-\mathrm{CH}_{2}-\mathrm{CH}=, J=7 \mathrm{~Hz}$ ), 1.66 (s, 3H, =CMeMe), 1.51 (d and $\mathrm{m}$, mixed peak of =CMeMe and $-\mathrm{CH} 2-, J_{\mathrm{d}}=8.5 \mathrm{~Hz}$ ).

${ }^{13} \mathrm{C} \mathrm{NMR}\left(\mathrm{CDCl}_{3}, 500 \mathrm{MHz}\right): \delta$ ppm 161.3, 138.1, 132.5, 123.1, 114.9, 33.8, 33.3, 27.2, 25.3, 24.8, 24.1, 17.6 .

\section{6-Amino-10-methyl-1,9-undecadiene (2e)}

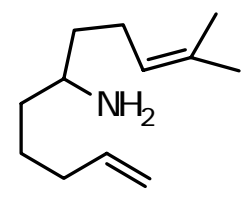

To a suspension of $\mathrm{LiAlH}_{4}(1.21 \mathrm{~g}, 31.8 \mathrm{mmol})$ in $80 \mathrm{~mL}$ of dry $\mathrm{Et}_{2} \mathrm{O}$ was added 10-methyl-1,9-undecadiene-6-one oxime (3.1 g, $15.9 \mathrm{mmol})$ dropwise at $-15{ }^{\circ} \mathrm{C}$. After the addition was complete the reaction mixture was heated at reflux overnight. The reaction mixture was cooled to $0{ }^{\circ} \mathrm{C}$ and quenched via sequential addition of $\mathrm{H}_{2} \mathrm{O}(7 \mathrm{~mL})$, $10 \%$ aqueous $\mathrm{NaOH}(7 \mathrm{~mL})$ and $\mathrm{H}_{2} \mathrm{O}(15 \mathrm{~mL})$. The mixture was stirred at ambient temperature for $30 \mathrm{~min}$, filtered and the filter cake was extracted with $\mathrm{Et}_{2} \mathrm{O}(15 \mathrm{~mL})$. The combined organic layers were dried over anhydrous $\mathrm{MgSO}_{4}$. The suspension was filtered and the filtrate was concentrated to give yellow oil. The residue was purified by vacuum distillation (bp $=42{ }^{\circ} \mathrm{C}$ at $0.02 \mathrm{mmHg}$ ) to afford 2.88g (99\%) of compound 2e.

${ }^{1} \mathrm{H}$ NMR ( $\mathrm{CDCl}_{3}, 500 \mathrm{MHz}$ ): $\delta$ ppm 5.72 (m, 1H, $\mathrm{CH}_{2}=\mathrm{CH}$ ), 5.02 (br m, $1 \mathrm{H}, \mathrm{Me}_{2} \mathrm{C}=\mathrm{CH}$ ), 4.92 (dd, 1H, CHH=, $J_{1}=17, J_{2}=2.5 \mathrm{~Hz}$ ), 4.85 (dd, $1 \mathrm{H}, \mathrm{CHH}=, J_{1}=9.25 \mathrm{~Hz}, J_{2}=1.25 \mathrm{~Hz}$ ), 2.60 (m, 1H, $\left.\mathrm{NH}_{2} \mathrm{CH}\right), 1.95$ (m, 4H, = $\left.\mathrm{CHCH}_{2}+\mathrm{Me}_{2} \mathrm{C}=\mathrm{CHCH}_{2}\right), 1.56$ (s, 3H, =CMeMe), 
1.53 (s, 3H, =CMeMe), 1.35 (m, 4H, - $\left.\mathrm{CH}_{2}-\mathrm{C}(\mathrm{N}) \mathrm{H}-\mathrm{CH}_{2}-\right), 1.19$ (m, 2H, $-\mathrm{CH}_{2^{-}}$), 1.03 (br s, $\left.2 \mathrm{H},-\mathrm{NH}_{2}\right)$.

${ }^{13} \mathrm{C} \mathrm{NMR}\left(\mathrm{CDCl}_{3}, 500 \mathrm{MHz}\right): \delta \mathrm{ppm} 138.7,131.4,124.3,114.4,50.7,38.1,37.5,33.8$, 25.6, 25.4, 24.7, 17.6.

HRMS : observed $\left[\mathrm{MH}^{+}\right]=182.1891$, calculated $\left[\mathrm{MH}^{+}\right]=182.1903$

\section{5-Amino-1,8-nonadiene (2f)}

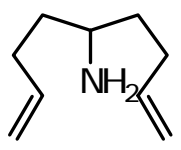

This compound was prepared in a fashion analogous to $\mathbf{2 b}$ utilizing nona-1,8dien-5-one oxime (2.45g, $16 \mathrm{mmol}), \mathrm{LiAlH}_{4}(1.25 \mathrm{~g}, 32 \mathrm{mmol})$ and $\mathrm{Et}_{2} \mathrm{O}(70 \mathrm{~mL})$ to give $1.5 \mathrm{~g}(67 \%)$ of $\mathbf{2 f}$.

${ }^{1} \mathrm{H}$ NMR (CDCl $3,300 \mathrm{MHz}$ ): $\delta$ ppm 5.80 (m, 2H, -CH=), 5.01 (br d, 2H, =CHH, J=16.8 Hz), 4.93 (br d, 2H, =CHH, J=10.2 Hz), 2.72 (m, 1H, CH), 2.13 (m, 4H, CH $), 1.50$ (m, 2H, $\mathrm{CH}_{2}$ ), 1.34 (m, 2H, $\mathrm{CH}_{2}$ ), 1.18 (br s, $2 \mathrm{H}, \mathrm{NH}_{2}$ ) .

${ }^{13} \mathrm{C} \mathrm{NMR}\left(\mathrm{CDCl}_{3}, 300 \mathrm{MHz}\right): \delta \mathrm{ppm} 138.6,114.5,50.2,37.2,30.4$.

\section{$N$-(p-Tolylsulfonyl)-2-but-3-enyl-5-methylpyrrolidine (3f)}

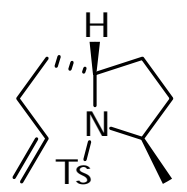

The reaction mixture, which was completely mono-cyclized to 2-but-3-enyl-5methylpyrrolidine $(0.4 \mathrm{mmol})$ using the catalyst $\mathrm{Sc}\left[\mathrm{N}(\mathrm{TMS})_{2}\right]_{3}$, was diluted with dried $\mathrm{CH}_{2} \mathrm{Cl}_{2}(2 \mathrm{~mL})$ followed by addition of pyridine $(97 \mu \mathrm{L}, 1.2 \mathrm{mmol})$ and TsCl $(114.4 \mathrm{mg}$, $0.6 \mathrm{mmol}$ ) at $-15{ }^{\circ} \mathrm{C}$. After stirring for $2 \mathrm{~h}$, the reaction mixture was diluted with $\mathrm{CH}_{2} \mathrm{Cl}_{2}$ $(10 \mathrm{~mL})$ and washed with $1 \mathrm{~N} \mathrm{HCl}(2 \times 3 \mathrm{~mL})$. The organic layer was dried over $\mathrm{MgSO}_{4}$, filtered, and concentrated in vacuo. The residue was subjected to column chromatography on silica gel (5\% EtOAc in $n$-hexane) to give $98.5 \mathrm{mg}$ (84\%) of title 
compound $\mathbf{3 f}$ as colorless solid. The ratio of trans:cis was determined by GC analysis to be 98:2.

${ }^{1} \mathrm{H}$ NMR (CDCl 3 , $300 \mathrm{MHz}$ ): (only trans) $\delta$ ppm 7.65 (d, 2H, $\mathrm{ArH}, J=8.4 \mathrm{~Hz}$ ), 7.18 (d, 2H, ArH, J=8.4 Hz), 5.68 (m, 1H, -CH=), 4.89 (m, 2H), 3.96 (quintet, 1H, NCH), 3.76 (m, 1H, NCH), 2.33 (s, 3H, $\mathrm{CH}_{3}$ ), 1.95 (m, 5H), 1.60 (m, 1H), 1.45-1.20 (m, 2H), 1.10 (d, $\left.3 \mathrm{H}, \mathrm{CH}_{3}, \mathrm{~J}=6.3 \mathrm{~Hz}\right)$.

${ }^{13} \mathrm{C}$ NMR (CDCl, $\left.300 \mathrm{MHz}\right): \delta$ ppm 142.5, 139.6, 137.7, 129.3, 126.9, 114.8, 59.9, 56.3, 33.1, 31.4, 30.4, 27.7, 21.4, 20.9.

\section{Syntheses of Proligands}

\section{$N, N^{\prime}$-bis(P,P-diisopropylthiophosphinyl)-2,2-dimethyl-1,3-propanediamine (4)}

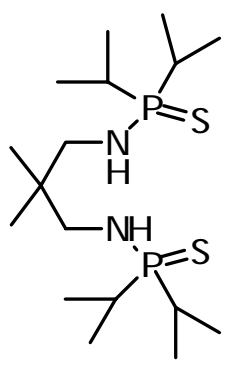

To a solution of 2,2-dimethylpropane-1,2-diamine (0.3 g, $2.5 \mathrm{mmol})$ and $N, N$ diisopropylethylamine $(1.96 \mathrm{~mL}, 11.25 \mathrm{mmol})$ in dichloromethane $(7.5 \mathrm{~mL})$ was added chlorodiisopropylphosphine $(0.8 \mathrm{~mL}, 5 \mathrm{mmol})$ dropwise with stirring at $0{ }^{\circ} \mathrm{C}$. The reaction mixture was allowed to reach $23^{\circ} \mathrm{C}$ and stirred overnight under inert atmosphere. The resulting white precipitate was rapidly filtered with care being taken to minimize exposure to air and the filter cake was washed with dry methylene chloride $(2 \times 3 \mathrm{~mL})$. Sulfur ( $0.17 \mathrm{~g}, 5.25 \mathrm{mmol}$ ) was then added in portions (exothermic) to the resulting mixture. The reaction mixture was heated to $80{ }^{\circ} \mathrm{C}$ with stirring for 30 min under argon. After cooling to ambient temperature, the mixture was concentrated in vacuo to give quantitative yield of $\mathbf{4}\left(\mathrm{mp}=143-144^{\circ} \mathrm{C}\right)$. 
${ }^{1} \mathrm{H}$ NMR (CDCl, $300 \mathrm{MHz}$ ): $\delta$ ppm 2.86 (s, 4H, $\mathrm{CH}_{2}$ ), 2.63 (br s, 2H, NH), 2.10 (m, 4H, $\mathrm{CH}), 1.17$ (d, 12H, CH,$J=6.9 \mathrm{~Hz}), 1.16$ (d, 12H, $\left.\mathrm{CH}_{3}, J=6.9 \mathrm{~Hz}\right)$.

${ }^{13} \mathrm{C}$ NMR $\left(\mathrm{CDCl}_{3}, 300 \mathrm{MHz}\right): \delta \mathrm{ppm} 46.936 .9\left(\mathrm{t}, J_{\mathrm{c}-\mathrm{p}}=6.0 \mathrm{~Hz}\right), 30.2\left(\mathrm{~d}, J_{\mathrm{c}-\mathrm{p}}=61.6 \mathrm{~Hz}\right)$, 23.6, 16.5, $16.2\left(\mathrm{~d}, J_{\mathrm{c}-\mathrm{p}}=2.7 \mathrm{~Hz}\right)$.

${ }^{31} \mathrm{P}\left(\mathrm{CDCl}_{3}, 300 \mathrm{MHz}\right): \delta \mathrm{ppm} 90.06$.

\section{$N, N^{\prime}$-bis(2-isopropylphenyl)ethane-1,2-diamine (6)}

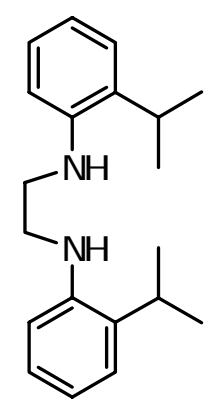

$N, N$ '-Bis(2-isopropylphenyl)oxalamide ${ }^{2}(2.0 \mathrm{~g}, 6.16 \mathrm{mmol})$ was reduced by addition to $\mathrm{LiAlH}_{4}(0.47 \mathrm{~g}, 12.3 \mathrm{mmol})$ in THF (30 mL) at ambient temperature and then heating the resulting mixture at reflux overnight. The reaction mixture was cooled to $0{ }^{\circ} \mathrm{C}$ and carefully quenched via sequential addition of $\mathrm{H}_{2} \mathrm{O}(0.5 \mathrm{~mL}), 15 \%$ aqueous $\mathrm{NaOH}$ $(0.5 \mathrm{~mL})$ and $\mathrm{H}_{2} \mathrm{O}(1 \mathrm{~mL})$. The mixture was stirred at room temperature for $2 \mathrm{~h}$, and anhydrous $\mathrm{MgSO}_{4}(1 \mathrm{~g})$ was added. After filtration, the solvent was evaporated in vacuo. The residue was purified by preparative TLC on silica gel, using $20 \%$ ethyl acetate in $n$ hexane for elution, to afford the title compound (6) $1 \mathrm{~g}$ (55\%) as a white solid (mp = 47$\left.48^{\circ} \mathrm{C}\right)$.

${ }^{1} \mathrm{H}$ NMR (CDCl, $300 \mathrm{MHz}$ ): $\delta$ ppm 7.15 (m, 4H, ArH), 6.76 (m, 4H, ArH), 4.03 (bs, 2H, $\mathrm{NH}$ ), 3.50 (s, 4H, $\mathrm{CH}_{2}$ ), 2.85 (m, 2H, $\left.\mathrm{CH}\right), 1.22$ (d, 12H, $\left.\mathrm{CH}_{3}, \mathrm{~J}=6.9 \mathrm{~Hz}\right)$.

${ }^{13} \mathrm{C}$ NMR (CDCl, $\left.300 \mathrm{MHz}\right): \delta$ ppm 144.6, 132.8, 126.8, 125.1, 117.9, 110.8, 43.5, 27.2, 22.3. 


\section{Literature Cited}

[1] a) Tamaru, Y.; Hoju, M.; Higashumura, H.; Yoshida, Z-I. J. Am. Chem. Soc. 1988, 110, 3994-4002. b) Kondo, T.; Okada, T.; Mitsudo, T-a. J. Am. Chem. Soc. 2002, 124, 186-187.

[2] a) Kim, Y. K.; Livinghouse, T.; Horino, Y. J. Am. Chem. Soc. 2003, 125, 9560. b) Kim, Y. K.; Livinghouse, T. Angew. Chem. Int. Ed., Engl. 2002, 41, 3645.

[3] Katritzky, A. R.; Cui, X-L; Yang, B.; Steel, P. J. J. Org. Chem. 1999, 64, 1979-1985 

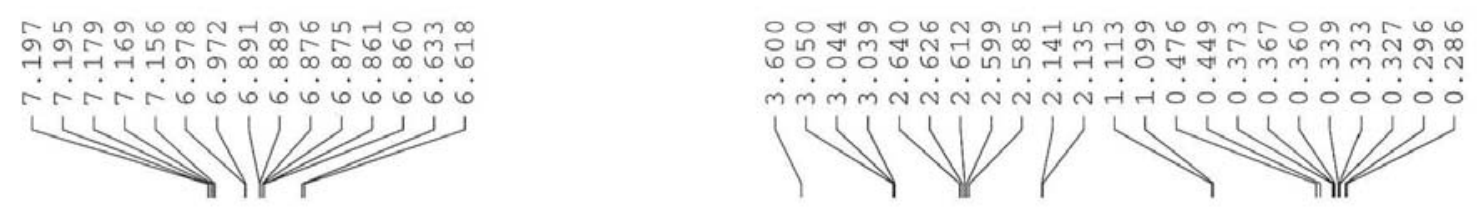

Ligand Exchange, Ligand $(6)+\mathrm{Sc}[\mathrm{N}(\mathrm{TMS}) 2] 3, \mathrm{p}-\mathrm{Xylene}$ as indicator 0 min.

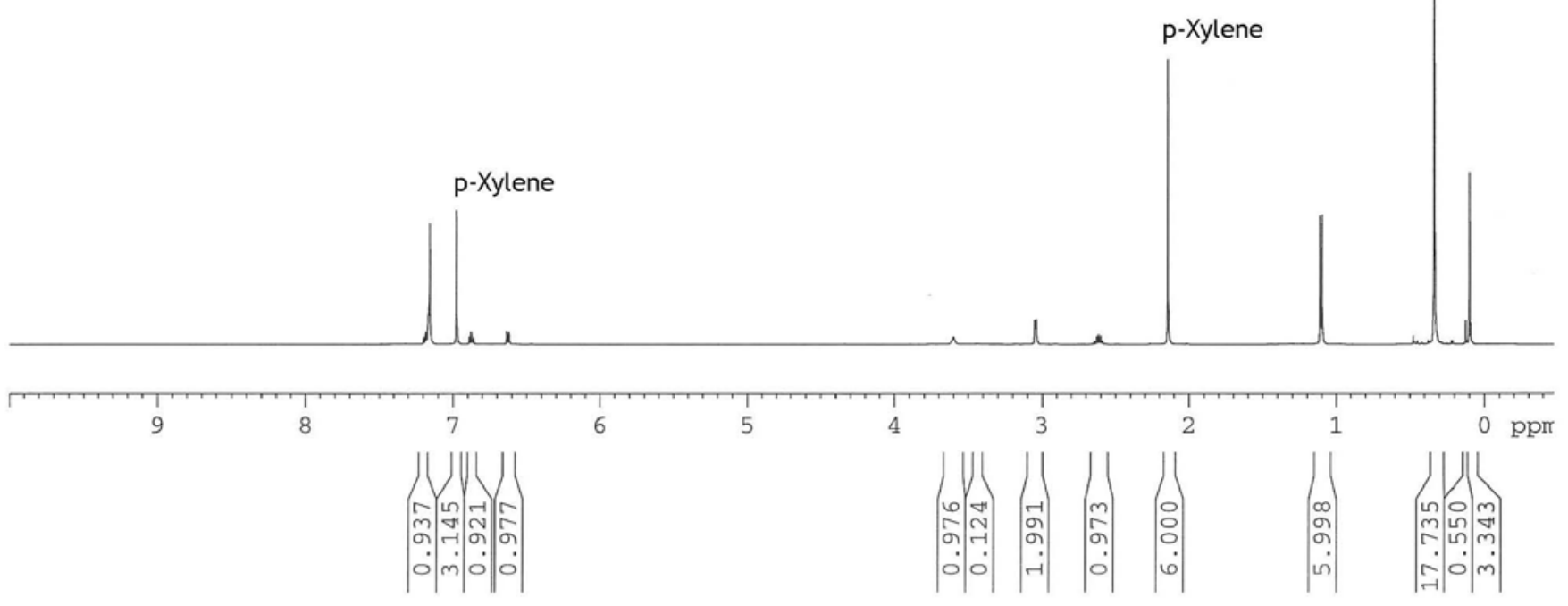



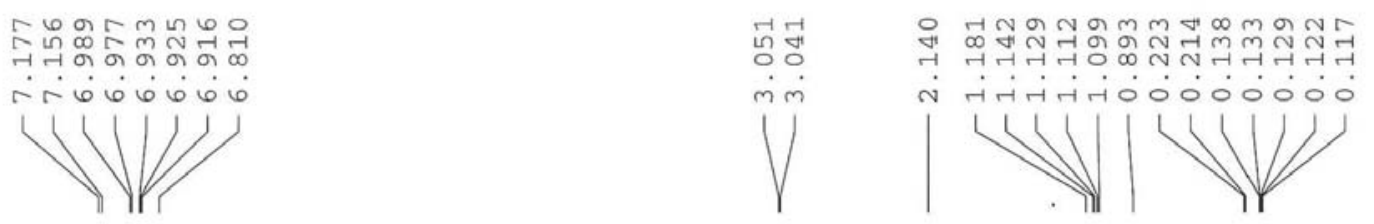

Ligand Exchange, Ligand $(6)+\mathrm{Sc}[\mathrm{N}(\mathrm{TMS}) 2] 3$, p-Xylene as indicator rxn. end

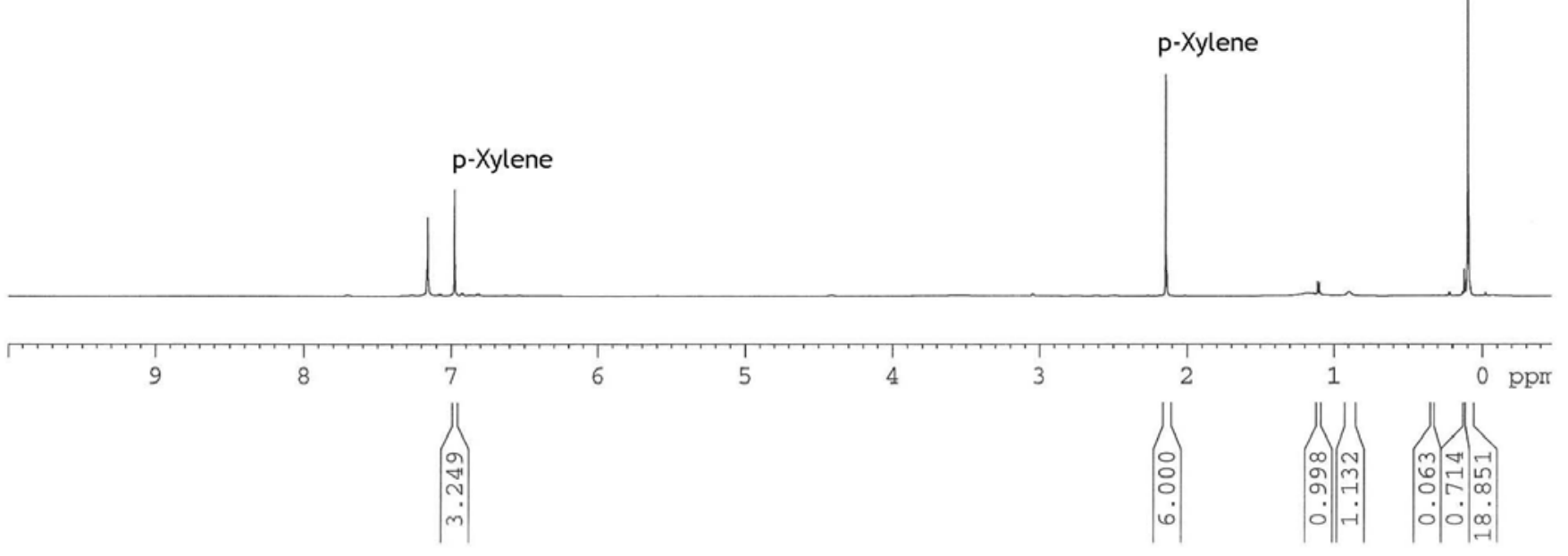




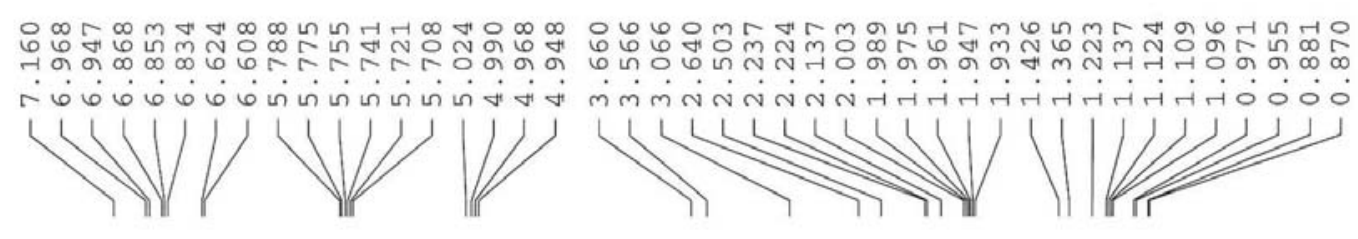

Hydroamination, 2-amino-5-hexene(2b), p-Xylene as indicator, 0 min

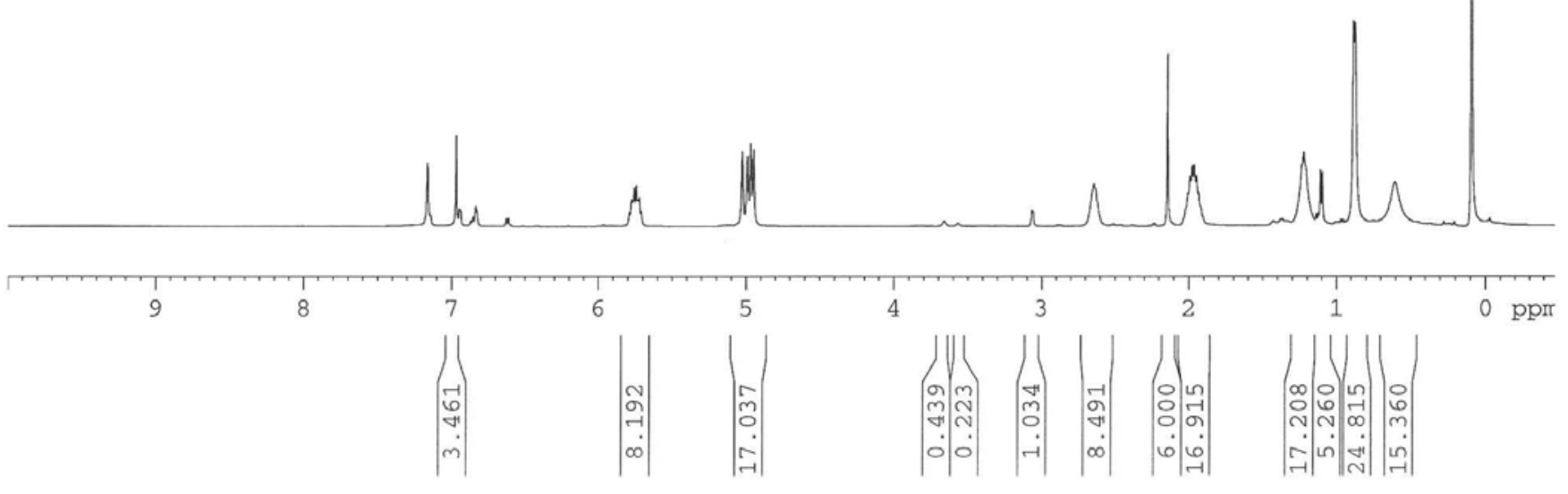



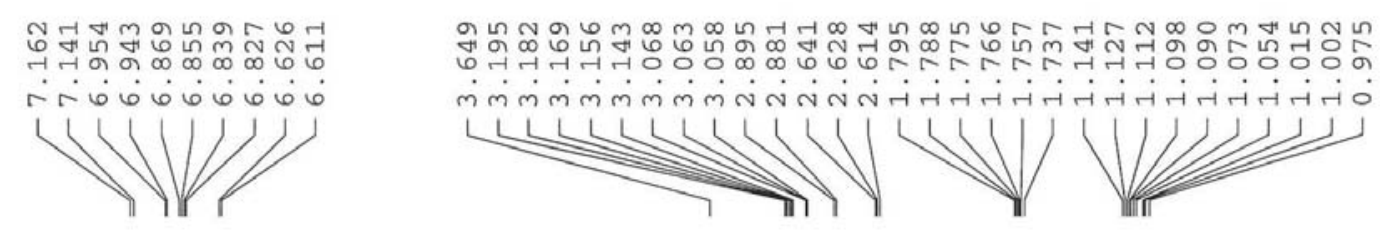

Hydroamination, 2-amino-5-hexene(2b), rxn. end with ratio

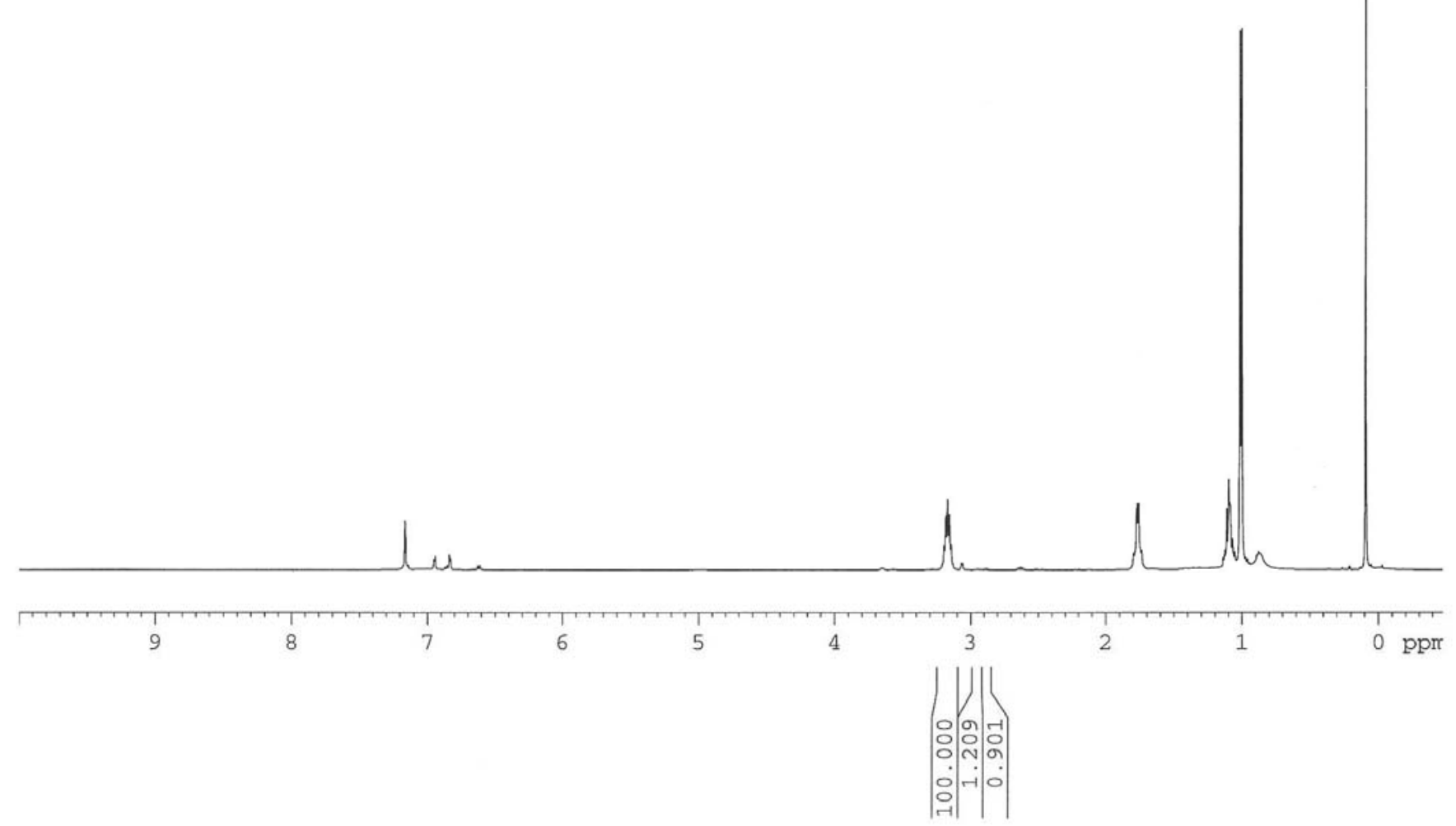




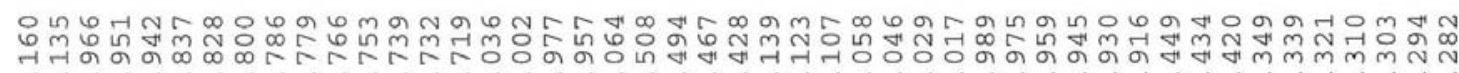

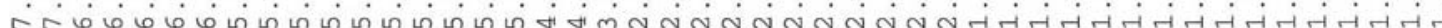

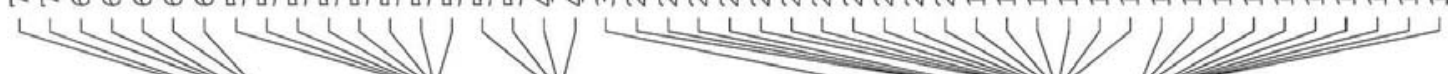

Hydroamination, 5-amino-1,8-nonadiene(2f), 0 min with p-Xylene

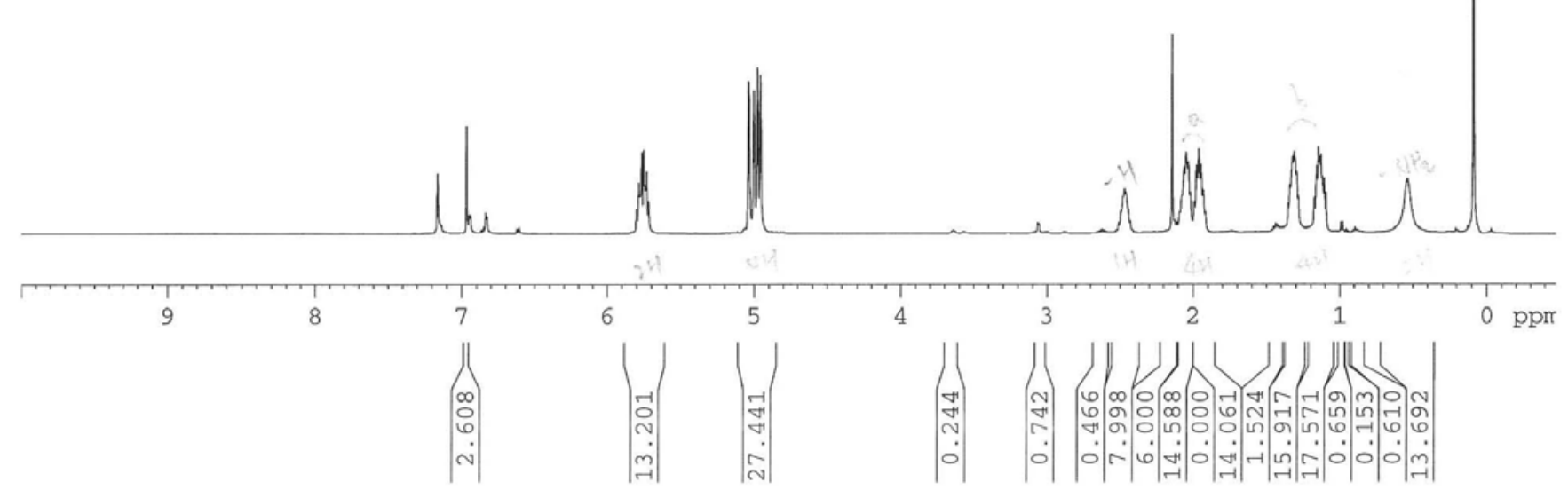


m心 ம

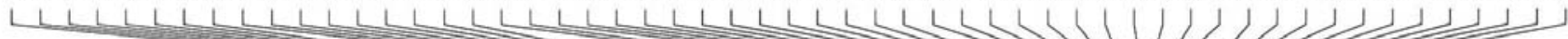
II

Hydroamination, 5-amino1,8-nonadiene, monocyclization completed

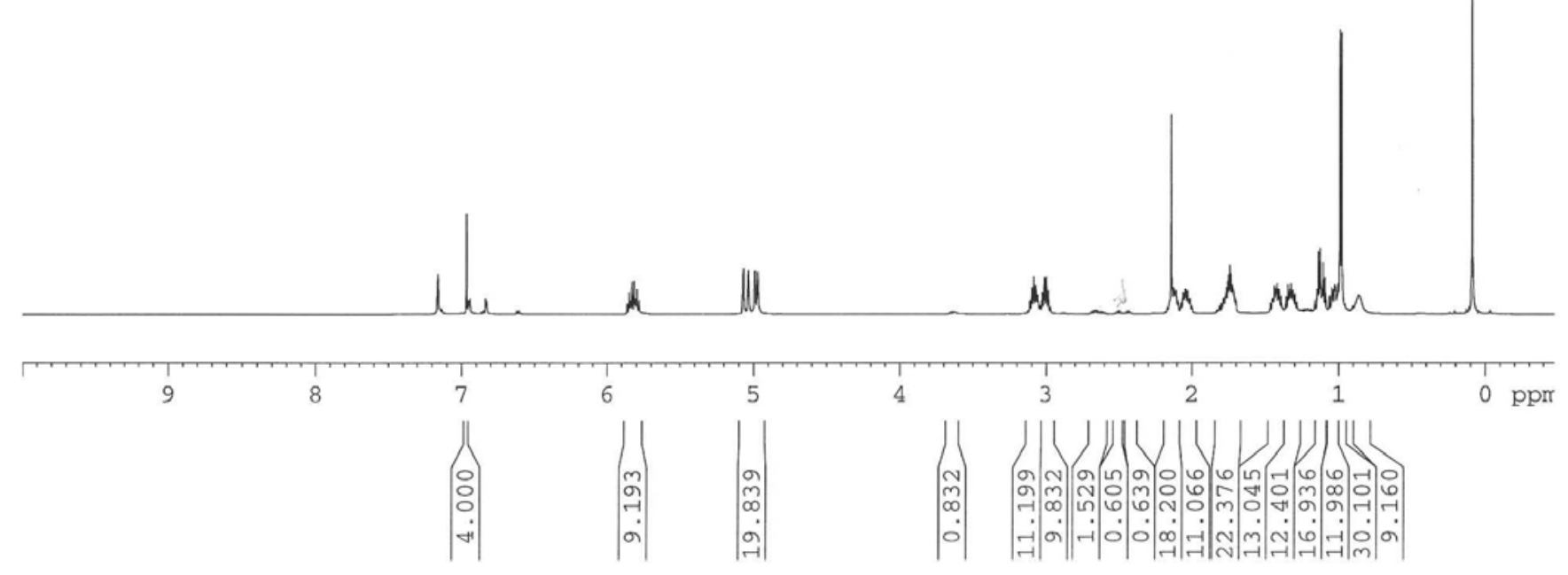




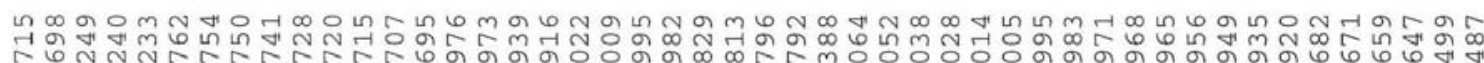

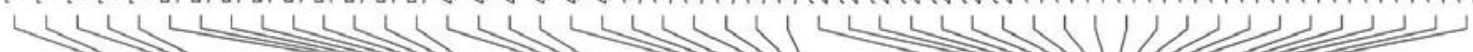
$\rightarrow>1$ ?

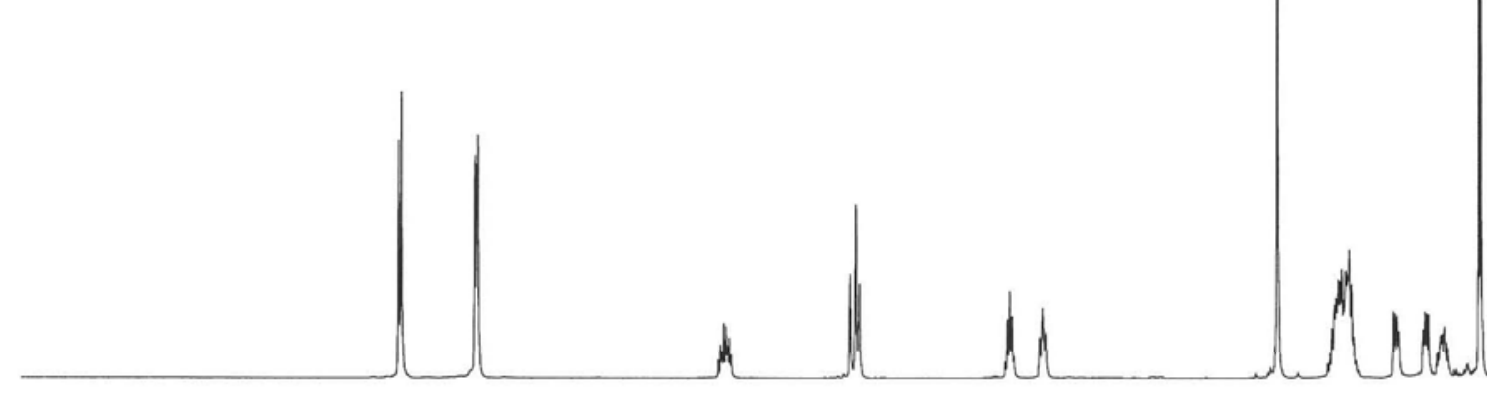

8

7

6

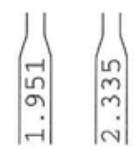

$\left|\begin{array}{l}\infty \\ \infty \\ 0 \\ 0\end{array}\right| \quad\left|\begin{array}{c}\sigma \\ 2 \\ \sigma \\ -1\end{array}\right|$

3

1

$0 \mathrm{ppr}$ 


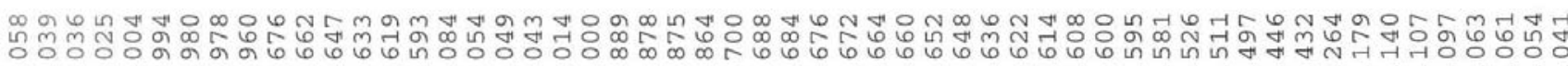
nं ம

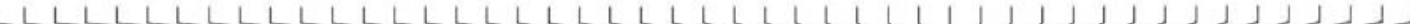
111

Hydroamination, 5-amino-1,8-nonadiene(2f), dicyclization completed
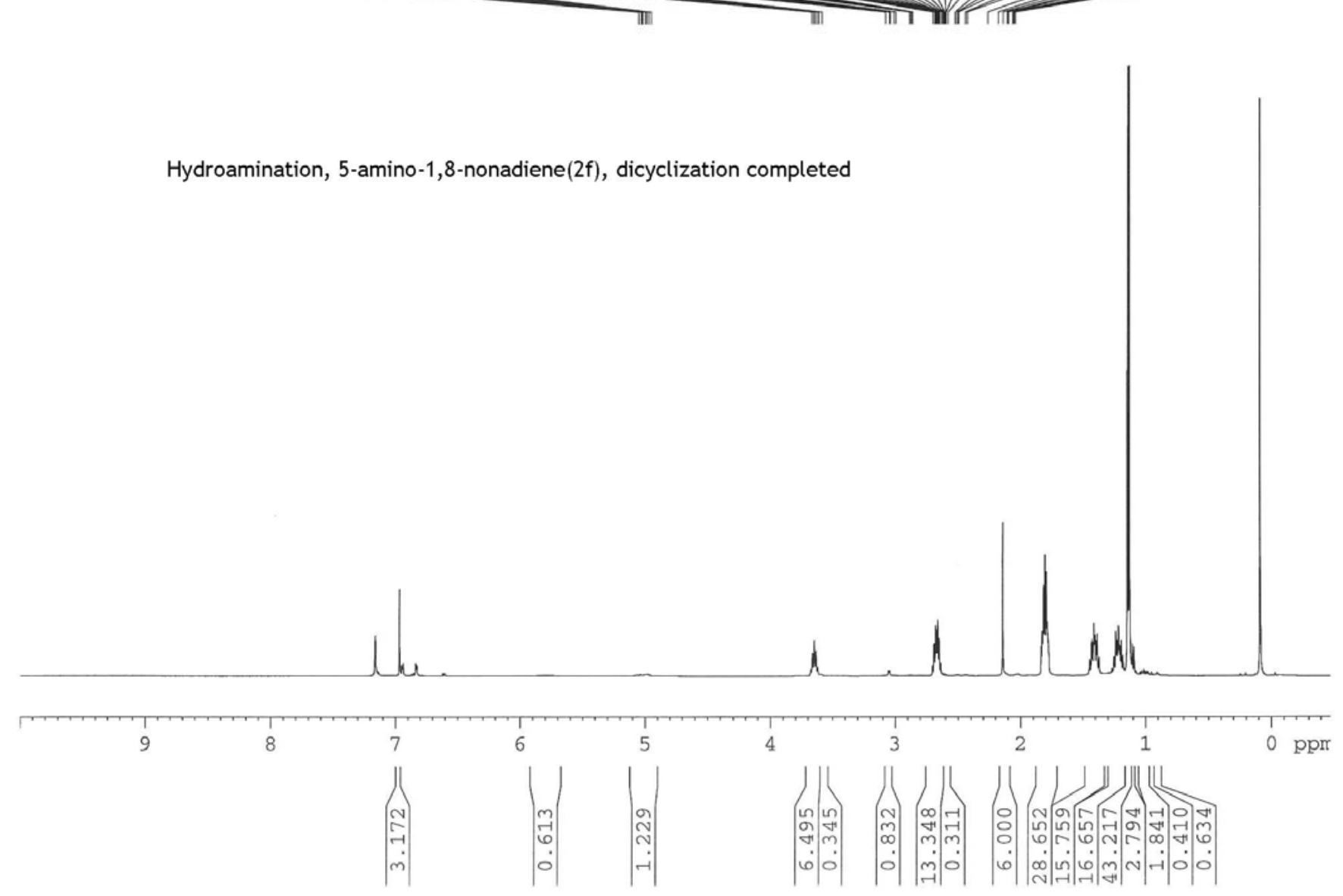


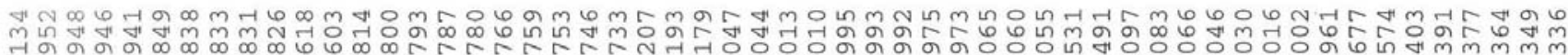

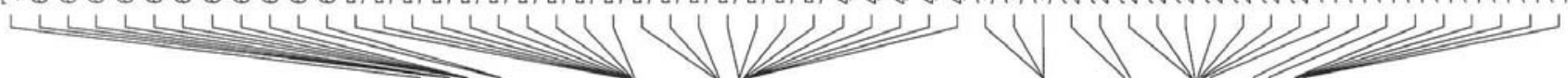
71

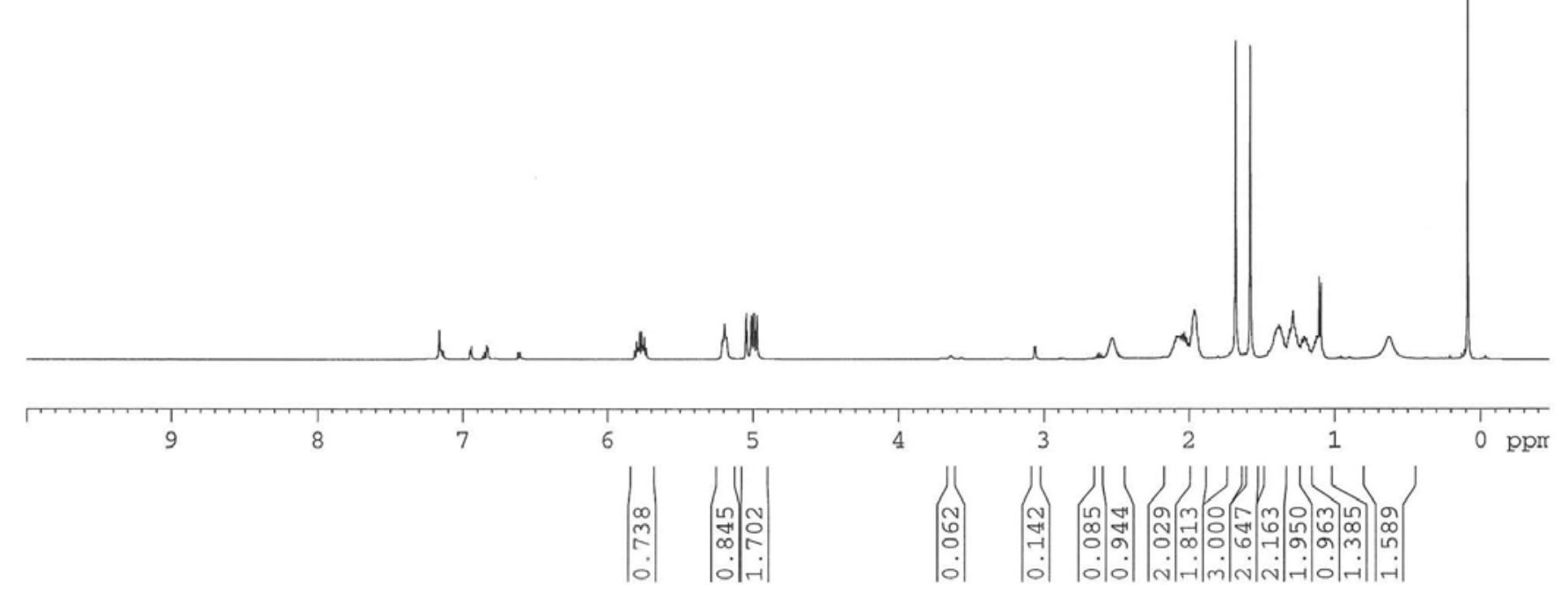




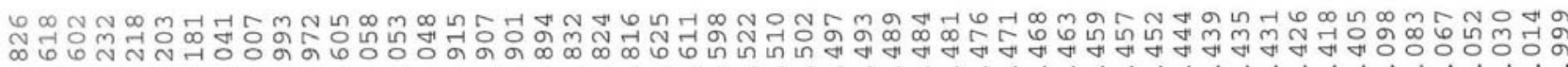
bด

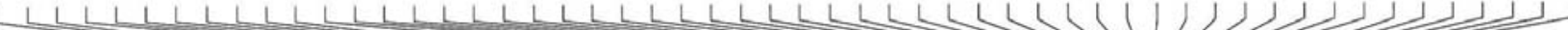

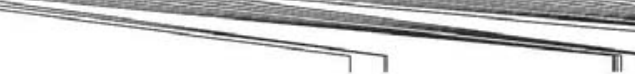

TII

Hydroamination, 6-amino-10-methyl-1,9-undecadiene(2e), monocyclization completed (>95\% conv.), 6-membered ring formed

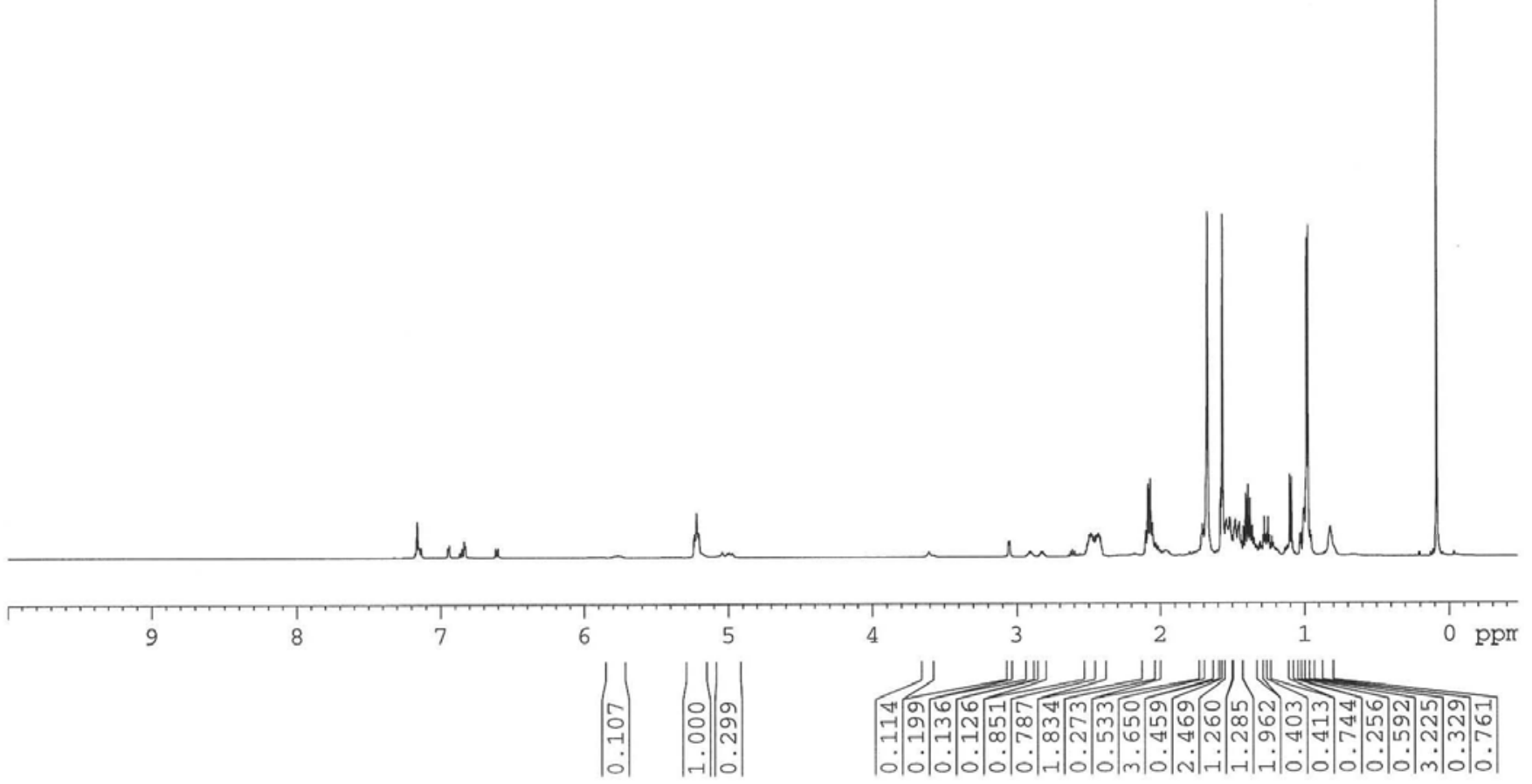




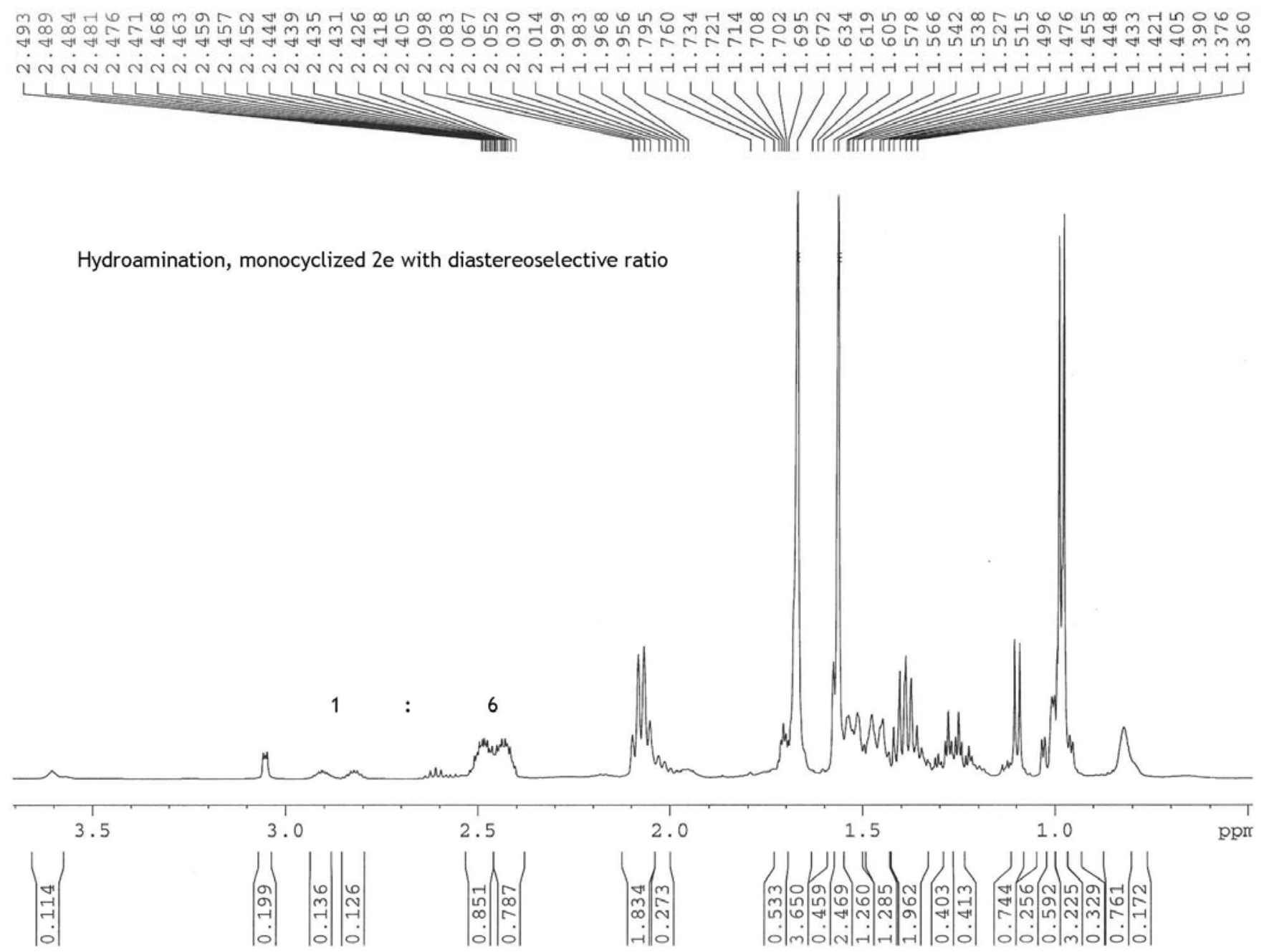

